EVIDENCE BASED PUBLIC HEALTH POLICY AND PRACTICE

\title{
Health impact assessment: assessing opportunities and barriers to intersectoral health improvement in an expanded European Union
}

\author{
Karen Lock, Martin McKee
}

J Epidemiol Community Health 2005;59:356-360. doi: 10.1136/jech.2004.024026

On 1 May 2004 the European Union (EU) underwent unprecedented enlargement, from 15 to 25 countries, increasing its population by $20 \%$ to over $\mathbf{4 5 0}$ million. Although EU law has limited specific competence in the area of health, its influence on other policy sectors such as agriculture, trade, and employment has wide ranging implications for health. Yet with the exception of provisions on communicable disease control and food safety, public health considerations have played little part in negotiations on EU accession. This paper argues for an intersectoral public health approach in the expanded EU. It reviews the legal basis for assessing the health impacts of policy in the EU and, using health impact assessment as a case study, it examines how well the new member states may be prepared to tackle intersectoral public health action within the constraints imposed by EU policy.

See end of article for authors' affiliations

Correspondence to: Dr K Lock, European Centre on Health of Societies in Transition, London School of Hygiene and Tropical Medicine, Keppel Street, London WCIE 7HT, UK; Karen. Lock@|shtm.ac.uk

Accepted for publication 12 December 2004
O n 1 May 2004 the European Union (EU) enlarged from 15 to 25 countries. This enlargement is important not only because of its scale but also because of the gap, in wealth and health, between the old and new member states. Although narrowing, on present trends it could be three decades or more before it closes. With the right policies in place, much could be achieved but identifying what those health promoting policies are, and which policies inadvertently damage health, may not be straightforward.

For health promotion it is necessary not only to look at mechanisms within the health sector but also to investigate the interaction between policy sectors. ${ }^{1}$ There is widespread agreement that health is low on the agenda in Europe. Except when faced with a major crisis (such as BSE or SARS), health issues rarely reach the political agenda.

Policies in new member states will be shaped increasingly by decisions taken by the EU. Yet the policy process is especially complex. ${ }^{2}$ Although the EU is committed to pursue a high level of health protection, policies that have an impact on health are dispersed throughout the Commission and important decisions in the Council of Ministers are often taken by nonhealth ministers. Since the 1992 Maastricht Treaty, the EU has been required to take account of the health impact of policies in other sectors yet there are many examples, from tobacco subsidies $^{3}$ to the Working Time Directive, ${ }^{4}$ where it has failed to do so.

Where the EU has acted, it has commonly adopted a narrow, disease focused approach, ignoring the wider determinants of health. This limited view of public health has remained throughout the enlargement process, with health playing little part in the accession negotiations. Yet the influence of EU law on other policy sectors such as agriculture and employment will have wide ranging health implications in the new member states. The EU is foremost an economic union concerned with free trade. Free trade brings benefits to health, for example the positive effects of economic growth, but it also brings hazards, with increased trade in substances harmful to health ${ }^{5}$ or economic policies that widen inequalities.

The process of accession is seen by many as one that will raise health standards in the acceding countries, bringing faster economic growth and a rise in living standards. Yet the removal of borders within Europe also brings potential threats to health, such as negative effects of EU law on national tobacco and alcohol control policies, ${ }^{5}$ and the consequences of internal market policies for example, on free movement of health professionals. ${ }^{6}$ However, less attention has been given to areas whose impact is less obvious but potentially even larger, such as agriculture. ${ }^{7}$ In these sectors, health is rarely on the policy agenda.

European politicians are not unique in ignoring health implications of major policies, although this is changing. A recent survey of 28 European governments (including the pre-2004 EU-15 and new member states) conducted by the EU high level committee for health found that, in all but four countries, health was recognised as a theme that cuts across policy areas, and all but one stated that they thought health might be relevant when developing polices in other sectors. ${ }^{8}$ Health is nominally taken into account in interministerial working groups and other intersectoral structures, audits of public administration, government budget and planning processes, and national and international requirements. However, 15 of the 28 stated

Abbreviations: HIA, health impact assessment; EU, European Union; EIA, environmental impact assessment; SEA, strategic environmental assessment 
that health is only considered opportunistically and is not included systematically in policy development.

It is important to develop processes that facilitate intersectoral health action. Health impact assessment (HIA) has the potential to increase the probability that the impact of policies is more likely to benefit than to harm health. ${ }^{19}{ }^{10}$ This paper reviews the existing legal basis for assessing the health impacts of EU policies and its implementation. Then, using the example of HIA, it considers facilitating factors and potential obstacles to intersectoral health policy formation. It asks how prepared are the public health sectors in new member states to address the population health impacts of non-health sector policies.

\section{THE EU BASIS FOR ASSESSING HEALTH IMPACTS OF NON-HEALTH SECTOR POLICIES}

Impact assessment methodologies are applied at the level of the EU and individual member states. The first European directive on environmental impact assessment (EIA) was adopted in 1985. ${ }^{11}$ There is also experience with social impact assessment, sustainability assessment, and integrated impact assessment. The last of these has been developed in the context of the complex challenge of identifying the implications of long range trans-border pollution and entails the integration of many diverse sources of data. A legal basis for assessing policy health impacts emerged in article 129 of the Maastrict Treaty (1993) and remained in article 152 of the Amsterdam Treaty (1997). Article 129 on public health stated that "health protection shall form a constituent part of the Community's other policies". However, as article 129 precluded harmonising legislation it had little influence on policy within member states. ${ }^{2}$ It also did little to foster an intersectoral approach to policy at a European level ${ }^{12}$ as despite the intentions of article 129 the means to carry it out are lacking. Article 152 of the Amsterdam treaty (ratified in 1999), stated that "a high level of human health protection shall be ensured in the definition and implementation of all community policies and activities". This strengthened the case for EU action, creating an opportunity to develop HIA as a means to achieve assessment of policy health impacts.

\section{OPPORTUNITIES AND BARRIERS}

It remains unclear who should be responsible for initiating HIA in the EU (the Commission, the European parliament, or member states). While there has been much discussion about integrating public health into other policies, the only examples of progress have been pilot HIA projects funded through Directorate General Sanco, as part of the EU Health Strategy 2000, and the current public health programme 2003-2008. ${ }^{13}$ An initial guide to assessing policy health impacts was published by Director General Sanco ${ }^{14}$ but has yet to be implemented. A more recent EC funded project aims to develop a generic methodology for HIA of EU policies and has been piloted on the European Employment Strategy. ${ }^{15}$

HIA is a cross cutting theme in the EU's current public health programme. Yet despite this activity, there remains some scepticism about its future potential at EU level. ${ }^{16}{ }^{17}$

Yet even if implemented more widely it is not clear how HIA would be integrated into policymaking. Health is, of course, not the only consideration in policymaking and final decisions will take account of a number of issues. Decision making may entail trade offs between different objectives, of which health will compete with economic, environmental, employment, and other considerations. The balance between these is political but a realistic aim is to ensure that possible health consequences of other policy sectors are at least not overlooked. In this way, any negative impacts on people's health and wellbeing can be removed or mitigated.
The voluntary status of HIA within the EU contrasts with that of EIA and strategic environmental assessment (SEA), which have a statutory legal basis. ${ }^{11}{ }^{18}$ While health protection is defined in EIA legislation, in practice, little has been achieved in integrating health considerations into the process, ${ }^{19}$ either being completely absent or restricted to technical issues such as levels of pollutants. The ownership of the EIA, SEA, or other impact assessment processes by agencies that have no direct stake in population health is seen as an obstacle to the effective integration of health concerns. Some recent European initiatives are attempting to strengthen the health elements of EIA. One approach is so called "integrated impact assessment tools". The EU is currently in the process of developing integrated approaches for screening new proposals. ${ }^{16}$ Another approach is to integrate aspects of HIA in a new European legal protocol on SEA, ${ }^{19}$ launched at the 5th Pan European Ministerial Conference on Environment in 2003. The protocol offers a potential mechanism to institutionalise HIA in European law. ${ }^{19}$

\section{THE USE OF HEALTH IMPACT ASSESSMENT IN AN EXPANDED EU}

Although HIA is not a legal requirement in the EU, 12 governments recognise its potential. ${ }^{8}$ Several of the pre-2004 member states already have considerable experience at applying HIA at local, regional, and national level including Germany, Ireland, UK, the Netherlands, and Sweden. Table 1 gives an overview of HIA applications in pre-2004 countries.

At least 8 of the 10 new member states have already considered HIA development or had experience of applying HIA or other intersectoral health improvement (table 2). A variety of methods have been used, all of which aim to assess the impact of a policy on public health.

The former communist new member states have some tradition of assessing health impacts of other policies. For example, in 1966 the public hygiene service in the former Czechoslovakia was given legal powers to assess health impacts, although in practice it had little influence on decisions. ${ }^{20}$ However, this formal "environmental health" role was narrow, focusing on adherence to technical standards. It contrasts with the emergence of broader public health approaches, creating a legacy of ambiguity about the concept of HIA.

Many new member states are developing more broadly based models of HIA, adopting multisectoral approaches to public health. For example, a Hungarian study exploring opportunities and barriers to using HIA in intersectoral policy ${ }^{21}$ started a process of HIA development by the ministry of health. ${ }^{22}$ Several other countries have been developing methods for HIA, supported by a range of capacity building activities (for example, Slovakia ${ }^{20}$ and Slovenia).

Various approaches have been developed, influenced by HIA methods elsewhere in Europe, particularly UK, Sweden, and the Netherlands. Such HIA toolkits are widely available on the internet and have many methodological similarities. ${ }^{1}$ A second approach, EHIA, is more specifically focused on the narrower environmental health perspective. Examples can be found in Poland, Hungary, Lithuania, Czech Republic, Slovakia, and Estonia, with EHIA being applied to projects such as air pollution and waste management. ${ }^{23}$ In the process of developing National Environmental Health Action Plans, ${ }^{24}$ the WHO Regional Office for Europe has worked with national environmental health agencies to develop an approach for integrating health into EIA. ${ }^{23}$ The EU has also funded technical assistance to strengthen EHIA. For example, an EU project in Poland, delivered by the Netherlands Ministry of Health and Netherlands School of Public Health, assists compliance with the EIA directive (D 
Table 1 Selected examples of how HIA has been applied in EU member states

\begin{tabular}{|c|c|c|}
\hline Country & $\begin{array}{l}\text { Administrative level at which } \\
\text { HIA conducted (national, } \\
\text { regional, local) }\end{array}$ & Policy sectors to which HIA has been applied \\
\hline Netherlands & $\begin{array}{l}\text { Health impact screening of } \\
\text { national policy }\end{array}$ & $\begin{array}{l}\text { Housing policy, }{ }^{37} \text { employment, }^{38} \text { environmental } \\
\text { energy tax }{ }^{31} \text { national budget }^{39}\end{array}$ \\
\hline \multirow[t]{3}{*}{ England } & National & $\begin{array}{l}\text { Burglary reduction initiative, } \\
\text { strategy }^{41}\end{array}$ \\
\hline & Regional & $\begin{array}{l}\text { London Mayoral strategies including transport, waste } \\
\text { disposal, economic development }{ }^{42}{ }_{43}\end{array}$ \\
\hline & Local & Regeneration projects, ${ }^{44}$ farmers markets \\
\hline \multirow[t]{2}{*}{ Wales } & National $^{32}$ & $\begin{array}{l}\text { Home energy efficiency scheme, Objective } 1 \\
\text { programme, }{ }^{45} \text { tourism (national botanical garden) }\end{array}$ \\
\hline & Local & $\begin{array}{l}\text { Power station development, landfill sites, housing } \\
\text { renewal scheme }\end{array}$ \\
\hline Sweden & $\begin{array}{l}\text { National } \\
\text { Local county council level }{ }^{47}\end{array}$ & $\begin{array}{l}\text { Agriculture, }{ }^{27} \text { alcohol policy } \\
\text { Various }\end{array}$ \\
\hline
\end{tabular}

Aarendonk, personal communication). EHIA and broader HIA should thus be seen as complementary applications.

Table 2 gives an overview of HIA activity in new member states.

\section{WHAT ARE THE OPPORTUNITIES FOR AND BARRIERS TO INTERSECTORAL HEALTH IMPROVEMENT USING HIA IN NEW MEMBER STATES?}

Despite the growing volume of HIA activity, there is still much uncertainty about how HIA can be used by all new member states. There are, however, lessons that can be drawn from other countries.
The important advantages conferred by HIA seem to have been the strengthening of understanding by policymakers of interactions between health and other policy areas with associated improvement in intersectoral relations. ${ }^{25}$ For example, in Slovenia, the involvement of a wide range of stakeholders in agriculture policy was a very important part of the process. Engagement of other sectors in HIA workshops widened the perspective, increased understanding of public health issues, and created shared agendas for future policy negotiations. Stakeholder involvement has been promoted as one of the strengths of HIA. ${ }^{9}$ However, such wide ranging stakeholder involvement may not always be necessary, nor useful particularly if conducted badly. ${ }^{26}$ Such participation has not been a feature of all HIAs in pre-2004 or

Table 2 HIA projects and development activity in new member states

\begin{tabular}{|c|c|c|c|}
\hline Country & HIA guidelines and/or training & HIA projects & $\begin{array}{l}\text { Administrative level at which HIA } \\
\text { conducted (national, regional, local) }\end{array}$ \\
\hline Czech Republic & $\begin{array}{l}\text { Health risk assessment (National Institute of } \\
\text { Public Health, Prague) } \\
\text { Health Impact Assessment in the Hygiene Service }\end{array}$ & $\begin{array}{l}\text { Development regional plan-strategic health plan } \\
\text { (planned) }\end{array}$ & Regional \\
\hline Estonia & $\begin{array}{l}\text { Guidelines for health impact assessment of } \\
\text { municipality policies (Estonian Centre for Health } \\
\text { Promotion 2002) }\end{array}$ & $\begin{array}{l}\text { Pilot project: health impact assessment in Rapla } \\
\text { municipality (in progress) }\end{array}$ & Local \\
\hline Hungary & National HIA Workshop (December 2003) & $\begin{array}{l}\text { Part of ongoing EU and WHO co-funded project } \\
\text { mapping the use and context of } \mathrm{HIA}^{49}\end{array}$ & National \\
\hline \multirow[t]{3}{*}{ Lithuania } & & $\begin{array}{l}\text { Annual report of the National health Council health } \\
\text { policy assessment }(1998,1999,2000) \\
\text { Toxic substances health impact assessment }(2003 \\
\text { planned) }\end{array}$ & National \\
\hline & & $\begin{array}{l}\text { Environmental health impact assessment of waste } \\
\text { management system, Siauliai region }\end{array}$ & National \\
\hline & & Development of HIA strategies & Regional \\
\hline Malta & & $\begin{array}{l}\text { Consideration of health issues in EIA for abattoir } \\
\text { waste incinerator (preliminary HIA) }\end{array}$ & Local \\
\hline Poland & $\begin{array}{l}\text { Technical assistance by the EU to strengthen } \\
\text { environmental health impact assessment to assist } \\
\text { compliance with the EIA directive (personal } \\
\text { communication) }\end{array}$ & $\begin{array}{l}\text { Part of ongoing EU and WHO co-funded project } \\
\text { mapping the use and context of } \mathrm{HIA}^{49}\end{array}$ & National \\
\hline Slovakia & $\begin{array}{l}\text { Health impact assessment in the hygiene } \\
\text { service } \\
\text { HIA workshop for nine central and eastern } \\
\text { European countries }(2002,2003)^{20}\end{array}$ & $\begin{array}{l}\text { Part of ongoing EU and WHO co-funded project } \\
\text { mapping the use and context of HIA } \\
\text {-WHO healthy cities network PHASE project are } \\
\text { developing: a HIA Toolkit; a HIA training module; a } \\
\text { resource pack to support planning for health and } \\
\text { sustainable development. Together with the Slovak } \\
\text { and Italian healthy cities network they are piloting the } \\
\text { draft HIA toolkit in } 2004 \text { in Trnava (Slovakia) and } \\
\text { Bologna (ltaly) }\end{array}$ & Local and national \\
\hline Slovenia & $\begin{array}{l}\text { Two day HIA training course run at National } \\
\text { ?Institute of Public Health }(2002)^{28}\end{array}$ & $\begin{array}{l}\text { Part of ongoing EU and WHO co-funded project } \\
\text { mapping the use and context of } \mathrm{HIA}^{49}\end{array}$ & National \\
\hline
\end{tabular}


post-2004 member states. For example, two assessments of the health impact of the EU's Common Agricultural Policy have been conducted by the Swedish Institute of Public Health. ${ }^{727}$ The most recent ${ }^{7}$ contributed to improved understanding by the agricultural sectors even though it was a desk based expert led study.

However, the implementation of HIA faces many obstacles, especially in such complex policy sectors as agriculture or environment. These include uncertainty about which stage of the policy process a HIA should be undertaken, deficiencies in the evidence base, lack of capacity, and difficulty embedding HIA in political and organisational culture.

While some countries have used the more limited EHIA approach, so far the most common approach to HIA has been one based on broad health determinants. This means that HIAs will confront considerable uncertainty about potential health impacts. For many policies, especially those implemented at a supranational level where even the immediate effects are often unclear, ${ }^{28}$ the causal pathways are complex, with the current evidence base patchy and often irrelevant to concrete policy options. ${ }^{29}$ Methods to assemble the evidence to enable HIA to contribute to decision making remain poorly developed ${ }^{29}{ }^{30}$ and often require a trade off between speed of working and depth of analysis. Other impact assessment methodologies, such as EIA, are also constrained by poor evidence. Perhaps HIA should learn from these and concentrate more on working within the constraints of the evidence rather than expecting the evidence to be available one day. In these cases HIA can usually show a direction of change, itself useful information, especially at early stages of policy development.

Ultimately, if HIA is to contribute to policy making, it must be integrated with administrative processes, in a similar way to EIAs. None of the new member states have yet institutionalised HIA, although in eight countries the ministry of health has been involved in some activity. However, this situation is little different from that in the pre-2004 members states. Despite considerable experience over several years only the Netherlands and Wales have had established national resourced HIA units operating as part of government. ${ }^{31}{ }^{32}$ In many countries HIAs have been conducted on an ad hoc basis, but some have had a clear mechanism to feed into government strategy making. Such approaches have included joint ministerial committees or interdepartmental working groups (for example, Slovenia, UK), although the public health benefit of these has not been proved and in the UK government HIA no longer seems to be a current political theme. A failure to embed HIA in the organisational structure of decision making bodies reduces the benefits that can accrue for intersectoral working. This was the case in British Columbia, Canada, where, after political changes, HIA fell off the policy agenda having previously been located within the cabinet. ${ }^{33}$ In Lithuania a more systematic approach has been piloted to embed HIA in administrative processes and structures. ${ }^{34}$ The project applied the policy arrangement model to analyse the political and

\section{What this paper adds}

- This paper adds a comprehensive review and analysis of the use of HIA in EU new members states.

- It adds an analysis of the constraints these 10 new countries may experience in tackling public health in intersectoral policy issues, and suggests how these may be tackled or in fact how they do not differ from the situation in pre-2004 member states. administrative circumstances to understand the opportunities and barriers for HIA implementation. However, despite some insights gained through this approach it was also found to have limitations both in designing practical recommendations and in giving insufficient recognition to the influence of different actors on the process. It is probable that difficulties in institutionalisation of HIA and intersectoral public health will be similar for all EU member states whatever approach is taken.

Yet even if a decision was made to institutionalise HIA, a lack of human resources remains an important constraint in many new members states. ${ }^{20} 2125$ The ability to assess health effects of policies in other sectors requires people with appropriate skills. In several of the new member states the public health community has yet to complete the transition from the old environmental health and hygiene services. In this system, HIA is interpreted as a narrow technical analysis, such as toxicological analysis of water or air samples. Modern public health, taking account of broader health determinants, such as the impact of policies on employment and income distribution, is a comparatively new discipline, although where investments have been made they have achieved considerable success, as in Hungary ${ }^{35}$ and the Baltic States. ${ }^{36}$ Another barrier to effective HIAs is a lack of mechanisms by which public health can work with or influence other policy sectors. The narrow focus of public health in former communist countries of central and eastern Europe contrasts with a broader multisectoral approach in some pre-2004 member states, such as the UK, the Netherlands, or the Nordic countries (although in others, such as Germany and France, the public health focus has also been narrow). In the absence of formal mechanisms for involvement, several countries have established ad hoc approaches, as in Slovenia and Malta.

HIA entails societal value judgements on the importance of HIA acceptability and trade offs in formulating recommendations. A WHO consensus paper on HIA lists equity, sustainable development, and ethical use of evidence as core values of an HIA.' Some groups involved in HIA, such as one from Slovakia, have identified the need for explicit values on which HIA can be built. ${ }^{20}$ During the communist era such values were simply assumed to exist in society and, as such, there was no need explicitly to consider them in developing policies. Much has changed since 1989, not least by virtue of the accession process, but the need for explicit consideration of the values underlying HIA and policymaking remains key in all EU member states.

\section{CONCLUSIONS}

The importance of the health consequences of other policies will grow after EU accession. Yet in many EU member states there remain considerable obstacles to implementing intersectoral approaches such as HIA. These include identification of the most appropriate methods to be used, institutionalisation of the process, development of mechanisms for intersectoral participation, and building public health capacity. While HIA is not the only way to ensure that health is on the broader policy agenda, it does offer one transparent

\section{Policy implications}

- The lack of structures and processes to address intersectoral public health issues in the enlarged EU

- The need to support new member states strengthen their skills and capacity for using intersectoral approaches such as health impact assessment 
mechanism to embed public health in sectors in which it is currently marginalised. Its strengths include the combination of a structured approach with flexibility of methods, as well as involvement of a wide range of stakeholders. ${ }^{19}$ Experiences so far show that it has potential to contribute to integration of policies in a range of sectors. HIA can add value to intersectoral health improvement by complementing other approaches such as interministerial working groups that have not necessarily been that successful. It is essential that practitioners and policy makers draw the lessons from the experience of HIA, in particular from evaluations planned and under way, so as to better support governments that are presiding over rapid processes of change to make "healthier" policy choices.

\section{Authors' affiliations}

K Lock, M McKee, European Centre on Health of Societies in Transition, London School of Hygiene and Tropical Medicine, London, UK

Funding: none.

Conflicts of interest: none declared.

\section{REFERENCES}

1 Lock K. Health impact assessment. BMJ 2000;321:1395-8.

2 McKee M, Mossialos E, Belcher P. The influence of European law on national health policy. Journal of European Social Policy 1996:6:268-9.

3 Gilmore A, McKee M. Tobacco control policy: the European dimension. Clin Med 2002;2:335-42.

4 Paice E, Reid W. Can training and service survive the European Working Time Directive? Med Educ 2004;38:336-8.

5 Gilmore $A B$, Österberg $E$, Heloma A, et al. Free trade versus the protection of health: the examples of alcohol and tobacco. In: Maclehose L, McKee M, Nolte E, eds. Health policy and European Union enlargement. Buckingham: Open University Press, 2004.

6 Nicholas S. Movement of health professionals: trends and enlargement. Eurohealth 2002;8:11-13

7 Schafer Elinder L. Public Health aspects of the EU Common Agricultural Policy: developments and recommendations for change in four sectors: fruit and vegetables, dairy, wine, tobacco. Stockholm: National Institute of Public Health, 2003.

8 Welsh Assembly government and Eurohealthnet. Health impact assessment and government policymaking in European countries. Cardiff: Welsh Assembly, 2003.

9 WHO. Health impact assessment: main concepts and suggested approach; the Gothenburg consensus paper. Copenhagen: WHO regional office for Europe, 1999.

10 Taylor L, Quigley R. Health impact assessment: a review of reviews. London: Health Development Agency, 2002.

11 European Commission. Council directive 85/337/EEC of 27 June 1985 on the assessment of the effects of certain public health and private projects on the environment. http://www.europa.eu.int/comm/environment/eia/full-legaltext/85337.htm

12 Mossialos E, Mckee M. A new European health strategy. BMJ 2000;321:6.

13 Decision No 1786/2002/EC of the European Parliament and of the Council of 23 September 2002 adopting a programme of Community action in the field of public health (2003-2008). hittp://www.europa.eu.int/eur-lex/pri/ en/oj/dat/2002.

14 European Commission. Ensuring a high level of health protection. Luxembourg: EC Health and Consumer Protection Directorate General, 2001. http://europa.eu.int/comm/health/ph_overview/Documents/ High_level_health_protection_en.pdf.

15 Scott Samuel A. Policy health impact assessment for the European Union. European Journal of Public Health 2003;13:18-19.

16 Hubel M, Hedin A. Developing health impact assessment in the European Union. Bull World Health Organ 2003;81:461-2.

17 Kreiger N, Northridge M, Gruskin S, et al. Assessing the health impact assessment: multidisciplinary and international perspectives. J Epidemiol Community Health 2003;57:659-62.

18 European Commission. Council directive 97/11/EC of 3 Mar 1997 amending directive $85 / 337 / E E C$ on the assessment of the effects of certain public and private projects. http://www.europa.eu.int/comm/environment/ eia/full-legal-text/9711.htm

19 Breeze C, Lock K. Health impact assessment as part of strategic environment assessment. Rome: WHO Regional Office for Europe, 2001

20 Gullis $\mathbf{G}$. Health impact assessment in CEE region: case of the former Czechoslovakia. Environmental impact assessment review 2004;24:169-76.
21 Ohr M. Getting health impact assessment into the policy process in Hungary. Conditions for developing healthy public policy. Budapest: Centre for Policy Studies, Central European University and Open Society Institute, 2003.

22 Ohr M. HIA conference, Budapest, 4-5 Dec 2003

23 Cherp A. Integrating health into EIA in Central and Eastern Europe in Interntational association for impact assessment conference proceedings. Netherlands: The Hague, 2002

24 WHO regional Office for Europe. National environmental health action plans (NEHAPS). Copenhagen: WHO regional Office for Europe, 2004. http:// www.who.dk/envhealthpolicy/Plans/20020807 1.

25 Lock K, Gabrijelcic M, Martuzzi M, et al. Health impact assessment of agriculture and food policies: lessons learnt from HIA development in the Republic of Slovenia. Bull World Health Organ 2003;81:391-8.

26 Parry J, Wright J. Community participation in health impact assessments: intuitively appealing but practically difficult. Bull World Health Organ 2003;81:388.

27 Dahlgren G, Nordgren P, Whitehead M. Health impact assessment of the EU Common Agricultural Policy. Stockholm: National Institute of Public Health, 1996.

28 Lock K, Gabrijelcic M, Martuzzi M, et al. Conducting a health impact assessment of the effect of accession to the European Union on national agriculture and food policy in Slovenia. Environmental impact assessment review 2004;24:177-88.

29 Parry J, Stevens A. Prospective health impact assessment: piffalls, problems and possible ways forward. BMJ 2001;323:1177-82.

30 Mindell J, Hansell A, Morrison D, et al. What do we need for robust quantitaive health impact assessment? J Public Health Med 2001;23:173-8.

31 Varela Put G, den Broeder L, Penris M, et al. Experience with HIA at national policy level in the Netherlands. Brussels: WHO Europe, ECHP Policy Learning Curve no 4, 2001.

32 Breeze C. The experience of HIA in Wales. In: Kemm J, Parry J, Palmer S, eds. Health impact assessment-concepts, theory, techniques and applications. Oxford: Oxford University Press, 2004.

33 Banken R. Strategies for institutionalising HIA. Brussels: WHO Europe, ECHP Policy Learning Curve no 1, 2001.

34 den Broeder L, Penris M, Varela Put G. Assessing opportunities for HIA implementation- the use of policy arrangement analysis. International association for impact assessment 24th annual conference, 24-30 Apr 2004, Vancouver, 2004

35 McKee M, Bojan F, White $M$, et al. Development of public health training in Hungary - an exercise in international co-operation. J Public Health Med 1995; 17:438-44

36 Kohler L, Eklund L. BRIMHEALTH. A successful experience in Nordic-Baltic cooperation in public health training. Eur J Public Health 2002;12:152-4

37 International Institute for the Urban Environment. Preliminary study: health impact assessment of housing policies in the Netherlands, (English translation 2001). Delft: IIUE, 1999

38 Van Putten D. Employment proposals and health effect screening. Amsterdam: TNO Arbeid (NSPH on behalf of the Intersectoral Policy of the Ministry of Health, Welfare and Sport), 1999.

39 NSPH. Health impact screening national budget 2000. Amsterdam: Intersectoral Policy, Ministry of Health, Welfare and Sport, 2000.

40 Hirschfield A, Boardman S, Douglass J, et al. Reducing burglary initiative rapid health impact assessment. Liverpool: University of Liverpool, Department of Civic Design, 2001

$41 \mathrm{Kemm}$ J. HIA and the national alcohol strategy for England. Health impact assessment-concepts, theory, techniques and applications, In: Kemm J, Parry J, Palmer S, eds. Oxford: Oxford University Press, 2004.

42 London Health Commission. Update on key messages from health impact assessments on Mayor of London draft strategies. London: London Health Commission, 2001.

43 London Health Commission. Evaluation of four health impact assessments on draft mayoral strategies for London. London: The London Health Commission, The Mayor of London and the London Health Observatory, 2003. http:// www.londonshealth.gov.uk/pdf/hiaeval.pdf.

44 Barnes R. HIA and urban regeneration: the Ferrier Estate. In: Kemm J, Parry J, Palmer S, eds. Health impact assessment-concepts, theory, techniques and applications. Oxford: Oxford University Press, 2004.

45 Breeze C, Kemm J. The health potential of the Objective 1; Programme for West Wales and the Valleys. Cardiff: The National Assembly for Wales, 2000.

46 Kemm J. Health impact assessment report: National Botanic Garden for Wales Welsh combined centres for public health. Cardiff: Health Impact Assessment Unit, National Combined Centres for Public Health, 2000:33.

47 Berensson K. HIA at the local level in Sweden. In: Kemm J, Parry J, Palmer S, eds. Health impact assessment-concepts, theory, techniques and applications. Oxford: Oxford University Press, 2004.

48 Volf $\mathrm{J}$, Janout $\mathrm{V}$. Health impact assessment in the hygiene service in the millennium. Hygiena 2001;46:148-56.

49 Wismar M. Mapping the use and context of health impact assessment across Europe: methodological issues and preliminary results from a 14-country study in International association for impact assessment, 24th annual conference 24-30 Vancouver, Apr 2004

50 WHO. Promoting and supporting integrated approaches for health and sustainable development at the local level across Europe ('PHASE'). Copenhagen: WHO Regional Office for Europe, 2004. 